\title{
Assessment of Volidity of Pont's Index and Establishment of Regression Equation to Predict Arch Width in Nepalese Sample
}

\author{
Dr Jyoti Dhakal,' Dr Rabindra Man Shrestha,2 Dr Ujjwal Pyakurel3 \\ 1:3Lecturer, ${ }^{2}$ Associate Professor, Dept of Orthodontics \\ Kantipur Dental College, Kathmandu, Nepal
}

Correspondence: Dr Jyoti Dhakal; email: orthosashwat@gmail.com

\section{ABSTRACT}

Objective: To evaluate the validity of Pont's index in Nepalese population and establish the regression equation to predict probable arch width from sum of the maxillary incisors.

Materials \& Method: The sample comprised of 50 female and 50 male subjects of the age ranging 17-24 years. Sum of the mesio-distal widths of the maxillary incisors were measured. Descriptive statistics, Coefficient of regression, and regression equation were calculated to predict the arch width in premolar and molar regions. Independent t-test was performed to find the difference between mean values of male and female subjects. Statistical analysis was done using SPSS version 17.0.

Result: Mean value of Pont's index ratio was 0.80 and 0.63 for premolar and molar respectively for Nepalese sample. Statistical analysis showed no significant difference between male and female in Pont's premolar and molar index. The correlation of coefficient for Sum of Incisors/Premolar width and Sum of Incisors/Molar width were 0.39 and 0.46 respectively.

Conclusion: Pont's analysis can be applied in Nepalese samples. There is no significant difference in values between male and female samples.

Key words: Mesio-distal width, Molar index, Nepalese population, Pont's index, Premolar index

\section{INTRODUCTION}

Various model analytical indices have been proposed in orthodontics to help in diagnosis and treatment planning. Majority of malocclusion can be treated with extraction or non-extraction approaches. Non-extraction method involves proximal stripping, distalization, labialization and arch expansion. Among these methods arch expansion is most commonly suggested but its stability has always been questioned.' Because of the availability of various indices, predicting the probable arch width is possible for clinicians. ${ }^{2-4}$ All of those indices show certain correlation between the arch length, arch width and mesiodistal width of the maxillary incisors.

Pont in 1909 proposed a method to predict arch width, which is popularly known as Pont's index. ${ }^{4}$ According to this method, by mere measurement of four maxillary incisors, arch width in premolar and molar region can be estimated. All of these measurements and predictions are related to maxillary arch and do not include mandibular arch. Pont obtained data from French population and did not include the sample size. However, he concluded that his work can be applied to different ethnic groups and suggested that the reliability of his index should be tested in other groups. According to Pont, in an ideal dental arch the ratio of combined mesiodistal incisal width to transverse arch width is 80 in premolar region and 64 in the molar region. The advantage of Pont's index is the simplicity of its application. But there has been big controversy regarding the relevance of this index. Predictions based on Pont's index are not consistent, resulting into agreement, disagreement, underestimation or overestimation of the Pont's values. ${ }^{2,5-17}$

The purpose of this study was to assess Pont's index in Nepalese samples and to establish the regression equation for the same. 


\section{MATERIALS AND METHOD}

Total sample included in the study were 100 Nepalese subjects with 50 male and 50 female of the age between 17-24 years. Data were collected among the patients visiting the Department of Orthodontic and students of Kantipur Dental College \& Hospital, Kathmandu. Inclusion criteria for the study were subjects with Class I molar and canine relation, straight facial profile without any previous history of orthodontic treatment. Subject with anomalies in tooth size and shape, deep bite, cross bite, rotations, large restorations were excluded from the study.

Alginate impression of maxillary arch was taken and cast poured with dental stone. Cast measurement of mesio-distal widths of maxillary incisors was done using digital Vernier caliper with the accuracy of $0.01 \mathrm{~mm}$. The sum of the maxillary incisor measurements was calculated. Maxillary arch widths in premolar and molar region were measured. Premolar arch width is termed as measured premolar value (MPV); which was measured from distal pit on occlusal surface of right first premolar to distal pit on occlusal surface of left first premolar. Arch width in molar area is termed as measured molar value (MMV), measured from mesial pit on occlusal surface of right first molar to left first molar. The predicted arch widths of premolar is termed as calculated premolar value (CPV) and in molar as calculated molar value (CMV); which were established using the formula originally proposed by Pont.

Descriptive statistics including mean, standard deviation and range, coefficient of regression, and regression equation were calculated to predict the arch width in premolar and molar regions. Independent t-test was performed to find the difference between mean values of male and female subjects. Statistical analysis was performed using SPSS version 17.0 software package. The data collection and analysis were done during June 2013 - Jan 2014 after the consent from the subjects and approval by the Institutional Review Committee. All samples were measured by the principal author.

\section{RESULT}

Descriptive statistics for overall sample is given in Table 1. Mean of the sum of maxillary incisors of total sample (SI) was $30.43 \mathrm{~mm}$ (SD 2.35). Mean measured premolar value (MPV) was 37.95 and mean measured molar value (MMV) was 47.94. Calculated premolar value (CPV) was 38.03 and calculated molar value (CMV) was 47.54. Pont's index for overall sample for premolar arch width was found to be 80.51 and molar arch width was 63.65. The Pont's premolar index was 82.37 and 78.64 for female and male respectively; and Pont's molar index was 65.38 and 62.79 for female and male respectively (Table 2). Overall measured value of premolar and molar width was 37.95 and 47.49 and calculated value was 38.03 and 47.54 respectively. In females, measured values for premolar and molar were 36.53 and 46.22 and calculated values were 37.51 and 46.89 respectively. In males, measured premolar and molar values were 39.39 and 49.26 where as calculated values were 38.56 and 48.20 respectively.

The present study showed no significant difference between Pont's values in female and male Nepalese samples for both premolar and molar index (Table 3).

Coefficients of regression ( $r$ ) were carried out to predict premolar and molar arch width by knowing the sum of maxillary incisor widths; which were found to be 0.39 for premolar and 0.46 for molar (Table 4). Regression equations for prediction of arch widths were derived from the formula.

$$
\begin{aligned}
& \text { Premolar arch width }=0.39(\mathrm{~S}-30.43)+37.95 \\
& \text { Molar arch width }=0.46(\mathrm{~S}-30.43)+47.94 \\
& \text { (Where ' } \mathrm{S} \text { ' is sum of maxillary incisors) }
\end{aligned}
$$

With the use of regression equation, prediction table was depicted to calculate the probable arch width from the sum of mesio-distal width of maxillary incisors (Table 5).

Table 1: Descriptive statistics and Pont's value for overall Nepalese samples ( $N=100)$

\begin{tabular}{|l|c|c|c|c|}
\hline \multicolumn{1}{|c|}{ Parameter } & Mean & SD & Min & Max \\
\hline Sum of incisors (SI) & 30.43 & 2.35 & 23.25 & 37.43 \\
\hline Measured premolar value (MPV) & 37.95 & 2.96 & 32.48 & 45.87 \\
\hline Measured molar value (MMV) & 47.94 & 3.34 & 41.78 & 58.85 \\
\hline Calculated premolar value (CPV) & 38.03 & 2.93 & 29.06 & 46.78 \\
\hline Calculated molar value (CMV) & 47.54 & 3.67 & 36.32 & 58.48 \\
\hline Pont's Premolar Index & 80.51 & 7.40 & 62.39 & 101.40 \\
\hline Pont's Molar Index & 63.65 & 5.47 & 52.15 & 75.82 \\
\hline
\end{tabular}


Table 2: Descriptive statistics and Pont's value for male and female Nepalese samples

\begin{tabular}{|l|c|c|c|c|}
\hline \multirow{2}{*}{\multicolumn{1}{|c|}{ Parameter }} & \multicolumn{2}{c|}{ Male (N=50) } & \multicolumn{2}{c|}{ Female (N=50) } \\
\cline { 2 - 5 } & Mean & SD & 30.01 & 2.07 \\
\hline Sum of incisors (SI) & 30.85 & 2.55 & 36.53 & 2.26 \\
\hline Measured premolar value (MPV) & 39.37 & 2.91 & 46.22 & 3.28 \\
\hline Measured molar value (MMV) & 49.26 & 3.58 & 37.51 & 2.58 \\
\hline Calculated premolar value (CPV) & 38.56 & 3.19 & 46.89 & 3.23 \\
\hline Calculated molar value (CMV) & 48.20 & 3.99 & 82.37 & 6.84 \\
\hline Pont's Premolar Index & 78.64 & 7.54 & 65.38 & 8.23 \\
\hline Pont's Molar Index & 62.79 & 5.45 & & \\
\hline
\end{tabular}

Table 3: t-test statistics for the difference between Pont's index of Nepalese female and male subjects

\begin{tabular}{|c|c|c|c|c|c|c|c|}
\hline & Gender & $\mathbf{N}$ & Mean & SD & SEM & $p$-value & Significance \\
\hline \multirow{2}{*}{ Pont's Premolar Index } & Male & 50 & 78.64 & 7.54 & 1.06 & \multirow{2}{*}{$\begin{array}{c}0.011 \\
(F=0.841)\end{array}$} & \multirow{2}{*}{ NS } \\
\hline & Female & 50 & 82.37 & 6.84 & 0.96 & & \\
\hline \multirow{2}{*}{ Pont's Molar Index } & Male & 50 & 62.79 & 5.45 & 0.77 & \multirow{2}{*}{$\begin{array}{c}0.114 \\
(F=0.485)\end{array}$} & \multirow{2}{*}{ NS } \\
\hline & Female & 50 & 64.52 & 5.40 & 0.76 & & \\
\hline
\end{tabular}

NS: Not significant $p<0.05$

Table 4: Coefficient of Regression derived for Nepalese sample

\begin{tabular}{|l|c|}
\hline \multicolumn{1}{|c|}{ Parameter } & r-value \\
\hline Sum of maxillary incisors and Measured Premolar Value (SI \& MPV) & 0.39 \\
\hline Sum of maxillary incisors and Measured Molar Value (SI \& MMV) & 0.46 \\
\hline
\end{tabular}

Table 5: Table of prediction value for Nepalese sample

\begin{tabular}{|c|c|c|c|c|}
\hline \multirow{2}{*}{ Sum of maxillary incisors (SI) } & \multicolumn{2}{|c|}{ Pont's original value } & \multicolumn{2}{c|}{ Prediction value } \\
\cline { 2 - 5 } & First premolar width & First molar width & First premolar width & First molar width \\
\hline 25 & 31.00 & 39.00 & 35.83 & 45.40 \\
\hline 26 & 32.50 & 40.90 & 36.22 & 45.90 \\
\hline 27 & 33.50 & 42.50 & 36.61 & 46.36 \\
\hline 28 & 35.00 & 44.00 & 37.00 & 46.82 \\
\hline 29 & 36.00 & 45.30 & 37.39 & 47.28 \\
\hline 30 & 37.50 & 46.87 & 37.78 & 47.74 \\
\hline 31 & 39.00 & 48.40 & 38.17 & 48.20 \\
\hline 32 & 40.00 & 50.00 & 38.56 & 48.66 \\
\hline 33 & 41.00 & 51.50 & 38.95 & 49.12 \\
\hline 34 & 43.00 & 53.00 & 39.34 & 49.58 \\
\hline
\end{tabular}




\section{DISCUSSION}

Clinical applicability of Pont's index has been evaluated by many investigators on various ethnic and racial groups to determine whether the index could be applied on different populations. . $^{6-9,12-17}$ Some investigators supported its use as a guide in expanding the dental arch. ${ }^{2,3}$ Worms $^{10}$ et al obtained lesser values than the calculated measurement. Similarly Nimkarn et al, Khin et al, Ordoubazary et al, Hong et al showed that Pont's indices overestimate the arch width. ${ }^{11-14}$ Lew and Dalidjan et al showed underestimation in values obtained using Pont's indices. ${ }^{15.16} \mathrm{Kim}$ et al found both over and underestimation in value obtained. ${ }^{17}$ The variation observed in different studies may possibly be attributed to genetic inheritance of the various races. The present study found significant and definite correlation between the sum of four maxillary incisors and arch widths in molar and premolar regions in agreement to
Pont's values. ${ }^{4}$ In our study premolar and molar index were found to be 80.51 and 63.65 respectively as compared to Pont's original values of 80 and 64 .

The noticeable difference in numerical values between Nepalese and other populations may be due to different genetic inheritance among the populations. Similar study by Shrestha ${ }^{18}$ in 2006 on Nepalese population showed the values similar to that of the original Pont's index.7 Another study done on Nepalese population in 2008 by Hong and Koirala stated that, Pont's index is not reliable for predetermining the arch width for Nepalese population. ${ }^{14}$ Previous studies on Nepalese mainly evaluated the applicability of Pont's index; while the present study also assessed the correlation between Pont's Index with Nepalese samples and established regression equation.

Agnihotri and Gulatib reported a significant and definite correlation between the sum of maxillary incisors and arch

Table 6: Comparison of various studies on the applicability of Pont's index

\begin{tabular}{|c|c|c|c|}
\hline Study & Sample & Remarks & Verdict \\
\hline $\begin{array}{l}\text { Pont }^{4} \\
\text { (1909) }\end{array}$ & $\begin{array}{l}\text { French } \\
\text { (NA) }\end{array}$ & Devised Pont's index, Premolar index 80, Molar index 64 & Agree \\
\hline $\begin{array}{l}\text { Stifter }^{2} \\
\text { (1958) }\end{array}$ & $\begin{array}{l}\text { Navaho Indians } \\
\text { (58) }\end{array}$ & $\begin{array}{l}\text { Significant correlation exist in ideal occlusion, } \\
\text { but not in normal occlusion }\end{array}$ & Agree \\
\hline $\begin{array}{l}\text { Joondeph, Riedel }{ }^{19} \\
\text { (1970) }\end{array}$ & $\begin{array}{l}\text { Orthodontic patients } \\
\text { (30) }\end{array}$ & $\begin{array}{l}\text { Found poor correlation, } \\
\text { Underestimation }\end{array}$ & Disagree \\
\hline $\begin{array}{l}\text { Worms, Speidel'10 } \\
\text { (1972) }\end{array}$ & $\begin{array}{l}\text { Navajo children } \\
\text { (224) }\end{array}$ & $\begin{array}{l}\text { Found poor correlation with ideal occlusion, } \\
\text { Overestimation }\end{array}$ & Disagree \\
\hline $\begin{array}{l}\text { Gupta, Sharma } 5 \\
\text { (1979) }\end{array}$ & $\begin{array}{l}\text { North Indians } \\
\text { (100) }\end{array}$ & $\begin{array}{l}\text { Found significant correlation, } \\
\text { Premolar index } 81.66 \text {, Molar index } 65.44\end{array}$ & Agree \\
\hline $\begin{array}{l}\text { Prasad, Valiathan } \\
\text { (1994) }\end{array}$ & $\begin{array}{l}\text { Indian (50) } \\
\text { Chinese (50) }\end{array}$ & $\begin{array}{l}\text { Premolar index 83.86, Molar index } 66.36 \\
\text { Premolar index 80.27, Molar index } 63.92\end{array}$ & Agree \\
\hline $\begin{array}{l}\text { Dalidjan, Sampson }{ }^{16} \\
\text { (1995) }\end{array}$ & $\begin{array}{l}\text { Australian Aborigines (80), } \\
\text { Indonesians (60) \& } \\
\text { Caucasians (60) }\end{array}$ & Found low correlation & Disagree \\
\hline $\begin{array}{l}\text { Karanth, Jayade } 20 \\
\text { (1998) }\end{array}$ & $\begin{array}{l}\text { Tibetan } \\
(50)\end{array}$ & Premolar index 79.56, Molar index 61.64 & Agree \\
\hline $\begin{array}{l}\text { Kim, Lee }{ }^{17} \\
(2000)\end{array}$ & $\begin{array}{l}\text { Korean } \\
\text { (119) }\end{array}$ & $\begin{array}{l}\text { Overestimate inter-premolar and } \\
\text { underestimate inter-molar value, } \\
\text { Premolar index } 81.96 \text {, Molar index } 62.55\end{array}$ & Disagree \\
\hline $\begin{array}{l}\text { Shrestha, Pradhan }{ }^{18} \\
(2006)\end{array}$ & $\begin{array}{l}\text { Nepalese } \\
(100)\end{array}$ & $\begin{array}{l}\text { Significant correlation, } \\
\text { Premolar index } 79.60 \text {, Molar index } 63.36\end{array}$ & Agree \\
\hline $\begin{array}{l}\text { Al-Omari, Duaibis }{ }^{21} \\
\text { (2007) }\end{array}$ & $\begin{array}{l}\text { Jordanians } \\
\text { (144) }\end{array}$ & $\begin{array}{l}\text { Pont's values low in all cases, } \\
\text { Overestimate }\end{array}$ & Disagree \\
\hline $\begin{array}{l}\text { Agnihotri, Gulatí } \\
\text { (2008) }\end{array}$ & $\begin{array}{l}\text { North Indians } \\
(100)\end{array}$ & $\begin{array}{l}\text { Definite correlation, } \\
\text { Premolar index } 81 \text {, Molar index } 65\end{array}$ & Agree \\
\hline $\begin{array}{l}\text { Hong, Koirala }{ }^{14} \\
\text { (2008) }\end{array}$ & $\begin{array}{l}\text { Nepalese } \\
(100)\end{array}$ & $\begin{array}{l}\text { Found very low correlation, } \\
\text { Overestimate }\end{array}$ & Disagree \\
\hline $\begin{array}{l}\text { Dhakal, Shrestha } \\
\text { (2014) }\end{array}$ & $\begin{array}{l}\text { Nepalese } \\
(100)\end{array}$ & $\begin{array}{l}\text { Current study, } \\
\text { Significant correlation, } \\
\text { Premolar index } 80.51 \text {, Molar index } 63.65\end{array}$ & Agree \\
\hline
\end{tabular}

NA $=$ Not available 
width in Northern Indian population conforming to Pont's values. Similar study by Gupta et al ${ }^{5}$ and Prasad \& Valiathan ${ }^{7}$ in Indian population also agreed with Pont's values. However, their studies showed difference in arch width between the gender groups while the present study did not show significant difference between male and female samples. Comparison of various studies on Pont's index and their results are given in Table 6. Some researchers described Pont's index as a poor clinical tool for predicting the arch width. However Pont's himself has stated that a similar study be done in other population too and verify the correctness of the index in other races. $^{4}$

\section{CONCLUSION}

One hundred samples with 50 male and 50 female with normal occlusion were evaluated to check the reliability of Pont's index on Nepalese population. It was concluded that significant correlation exist between the sum of the maxillary incisors and maxillary interpremolar and intermolar arch widths in overall, male and female samples.

Coefficients of regression were depicted and prediction table was devised to calculate the probable arch width from the sum of mesio-distal width of maxillary incisors.

\section{ACKNOWLEDGEMENT}

We would like to thank Dr Sujita Shrestha, Lecturer, Dept of Community \& Public Health Dentistry for her help in statistical analysis and Dr Poojan Thapaliya, intern for her help in data collection

\section{REFERENCES}

1. Kahl-Nieke B, Fischbach H, Schwarz CW. Treatment and post retention changes in dental arch width dimensions a long-term evaluation of influencing cofactors. Am J Orthod 1996; 109:368-78.

2. Stifter J. A study of Pont's, Howes' Rees' Neff's and Bolton's analyses on Class I adult dentitions. Angle Orthod 1958; $28(4): 215-25$.

3. Rees DJ. A method for assessing the proportional relation of apical bases and contact diameters of the teeth. Am J Orthod 1953; 39:695707.

4. Pont A. Der zahn-Index in der orthodontie. ZeitschriftfürZahnärtzlicheOrthopädie 1909; 3:306-21.

5. Gupta DS, Sharma VP, Agrawal SP. Pont index applied on Indians. Angle Orthod 1979; 49(4):269- 27.

6. Agnihotri G, Gulati M. Maxillary molar and premolar indices in North Indians: A dimorphic study. Internet J Biol Anthropol 2008; 2:1.

7. Prasad K, Valiathan A .A model analysis: Comparison of norms for Indians and Chinese using Pont's Index . J Ind Orthod Soc 1995; 26:1-5.

8. Sridharan K, Madhusudhan V, Srinivasa H, Mahobia Y. Evaluation of validity of Pont's analysis in Tumkur population. J Dental Sci Res 2011 ; 2:41-9.

9. Korkhaus G, Gebi G. Handbuch der Zahnheilkunde Kiefer- und GesichtsorthopadieBd VI. Munchen: Bergmann, 1939.

10. Worms FW, Speidel TM, Meskin LH, Isaacson RJ. The validity of Pont's Index as an orthodontic diagnostic tool. I.A.D.R Meeting. North America, 1969:213.

11. Nimkarn Y, Miles PG, O'Reilly MT, Weyant RJ. The validity of maxillary expansion indices. Angle Orthod 1995; 65(5):321-6.

12. Khin MT, Winn T, Abdullah N, Jayasinghe JAP, Chandima GL. The maxillary arch and its relationship to cephalometric landmarks of selected Malay ethnic group. Malaysian J Med Sci 2005; 12(1):29-38.

13. Ordoubazary M, Zafarmand AH, Madani A, Ordoubazary A. Comparison of Pont's and Korkhaus indices at different populations. Hell Orthod Rev 2007; 10(2):67-74.

14. Hong Q, Tan J, Koirala R, Lina Y, Shimizu T, Nakano K, et al. A study of Bolton's and Pont's analysis on permenant dentition of Nepalese. $J$ Hard Tissue Biol 2008; 17(2):55-61.

15. Lew K. The effect of variations in the mandibular plane angle on the Pont's Index. Funct Orthod 1991; 8(2):24-7.

16. Dalidjan M, Sampson W, and Townsend G. Prediction of dental arch development: An assessment of Pont's Index in three human populations. Am J Orthod 1995; 107:465-75.

17. Kim SH, Lee KS. An evaluation of the adequacy of Pont's Index. Kor J Orthod 2000; 30(1):115-26.

18. Shrestha RM: Analysis of Pont's index in Nepalese population. J Nep Dent Asso 2006; 8(1):10-4.

19. Joondeph DR, Riedel RA, Moore AW. Pont's Index: A clinical evaluation. Angle Orthod 1970; 40(2):112-8.

20. Karanth D, Jayade VP: An orthodontic study of Tibetan population .Aus Orthod J; 1998:15:2:93-100.

21. Al-Omari IK, Duaibis RB, Al-Bitar ZB. Application of Pont's Index to a Jordanian population. Eur J Orthod 2007; 29(6):627-31. 